\title{
Perbedaan Fungsi Ventrikel Kiri pada Anak Gizi Kurang dan Gizi Normal dengan Metode Myocardial Performance Index
}

Putria Rayani Apandi, Sri Endah Rahayuningsih, Rahmat Budi Kuswiyanto

Departemen Ilmu Kesehatan Anak Fakultas Kedokteran Universitas Padjadjaran, Bandung

Latar belakang. Gizi kurang pada anak menyebabkan perubahan pada komposisi tubuh, berupa berkurangya masa otot jantung yang akan menyebabkan kelainan pada fungsi kardiovaskuler. Myocardial performance index (MPI) adalah pemeriksaan fungsi ventrikel yang tidak terpengaruh geometri jantung. Pemeriksaan MPI pada anak gizi kurang belum pernah dilakukan sebelumnya.

Tujuan. Penelitian ini bertujuan untuk menilai perbedaan fungsi ventrikel pada gizi kurang dan gizi normal.

Metode. Rancangan penelitian ini adalah potong lintang yang dilakukan pada anak sekolah berumur 6-11 tahun di Kotamadya Bandung selama September - Desember 2014 di 10 Sekolah Dasar. Subyek penelitian di pilih secara random kemudian dibagi menjadi gizi kurang dan gizi normal berdasarkan WHO 2007. Fungsi ventrikel diukur dengan ekokardiografi transtorakal dengan metode Myocardial performance index. Uji t berpasangan dipakai untuk membedakan fungsi ventrikel kiri pada gizi kurang dengan signifikansi $\mathrm{P}<0,05$.

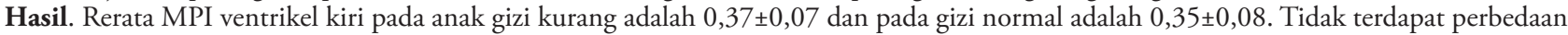
yang bermakna fungsi ventrikel kiri dengan metoda Myocardial Performance Index pada kedua kelompok.(CI95\%:-0,012-0,058 P:0,191) Kesimpulan. Fungsi ventrikel kiri pada anak gizi kurang dan gizi normal yang diukur dengan Metode myocardial performance index tidak berbeda bermakna. Sari Pediatri 2021;23(2):110-14

Kata kunci: anak, gizi kurang, fungsi ventrikel kiri, myocardial performance index

\section{The Difference of Left Ventricular Function in Malnourished and Well- Nourished Children by Myocardial Performance Index Method}

Putria Rayani Apandi, Sri Endah Rahayuningsih, Rahmat Budi Kuswiyanto

Background. Malnutrition resulting in cumulative deficits of energy, protein, or micronutrient that may affect heart structure and function. Myocardial performance index (MPI) is independent of ventricular geometry. To the best of our knowledge this is the first study which measure of left ventricular function on malnourished children compared with well-nourished children by MPI methods.

Objective. This study was conducted to detect the difference of myocardial function in malnourished children.

Methods. This was a cross sectional study on children aged 6-11 years which was conducted during September-November 2014 on 10 Elementary schools in Bandung. The subjects were selected randomly according to WHO 2007 into divided into 2 groups and age and sex matched: group 1: malnourished children and group 2: well-nourished according to WHO 2007 which randomly selected, then we performed transthoracic echocardiography with Myocardial Performance Index methods to measure left ventricular function. T paired test was used to assess the difference of both groups.

Result. The mean of the MPI of the left ventricular in malnourished children was $0.37 \pm 0.07$ and in well-nourished children were $0.35 \pm 0.08$. There was no significant difference between left ventricular function in malnourished children and well-nourished children by myocardial performance index methods (CI95\%:-0.012 - 0.058 p: 0.191)

Conclusion. No significant difference in left ventricular function by MPI methods between malnourished and well-nourished children. Sari Pediatri 2021;23(2):110-14

Keyword: malnourished children, MPI, Left ventricular function

Alamat korespondensi: Putria Rayani Apandi. Departemen Ilmu Kesehatan Anak Fakultas Kedokteran Universitas Padjadjaran, Bandung. Email: putriadirgantara@ gmail.com 
Putria Rayani Apandi dkk: Perbedaan fungsi ventrikel kiri pada anak gizi kurang dan gizi normal dengan metode MPI

G izi kurang merupakan masalah kesehatan dunia. World Health Organization (WHO) memperkirakan bahwa gizi kurang berkontribusi pada 54\% mortalitas anak di dunia. Gizi kurang diperkirakan sudah meningkatkan risiko kematian dan risiko ini akan meningkat terutama pada gizi buruk. Prevalensi gizi kurang di Provinsi Jawa Barat adalah 4,6\%. Menurut kelompok umur berdasarkan riset kesehatan dasar (RISKESDAS) tahun 2013, prevalensi gizi kurang adalah 9,6\% untuk balita, $11,2 \%$ untuk usia 5-12 tahun, dan $11,1 \%$ untuk usia 1-15 tahun. ${ }^{1,2,3}$

Pada anak gizi kurang didapatkan perubahan pada komposisi tubuh, berupa masa otot jantung berkurang sehingga dapat menyebabkan kelainan pada fungsi kardiovaskuler berupa hipotensi, aritmia, disfungsi ventrikel sampai kardiomiopati. ${ }^{4}$

Penelitian ini bertujuan untuk mencari apakah ada perbedaan pada fungsi ventrikel kiri anak gizi kurang dibandingkan dengan gizi normal yang diperiksa dengan metode MPI yang diharapkan lebih akurat. Manfaat dari penelitian ini diharapkan dapat diperoleh data mengenai hubungan status gizi dengan penurunan fungsi ventrikel kiri sehingga dapat memberikan informasi berbasis bukti, juga dapat meningkatkan kewaspadaan terhadap gizi kurang.

\section{Metode}

Rancangan ini merupakan penelitian deskriptif analitik dengan desain penelitian potong lintang. Penelitian dilakukan pada bulan September 2014 - April 2015 yang melibatkan 60 anak dan. Kriteria inklusi adalah anak berusia 6-11 tahun yang dibagi menjadi 2 kelompok, yaitu gizi normal dan gizi kurang menurut WHO 2007. Pengambilan sampel penelitian didahului dengan adanya surat izin dari Dinas Pendidikan Kotamadya Bandung. Sampel penelitian dipilih 15 sekolah dasar negeri secara simple random sampling dan dari 789 sekolah dasar di kotamadya Bandung lima di antaranya menolak karena sedang ada kegiatan disekolahnya. Dari 10 sekolah didapatkan 30 anak gizi kurang yang dipilih secara simple random sampling. Kemudian dilakukan matching berdasarkan usia dan jenis kelamin untuk anak dengan gizi normal yang dipilih 30 anak secara simple random sampling. Kriteria eksklusi adalah anak dengan kelainan jantung, penyakit kronis seperti talasemia, keganasan, dan anak dalam pengobatan kemoterapi.

Penelitian ini telah disetujui oleh komite etik Rumah Sakit Dr. Hasan Sadikin Bandung. Setelah orang tua anak menandatangani formulir persetujuan, kemudian dilakukan pengisian kuesioner dan pemeriksaan fisik. Pemeriksaan transtorakal ekokardiografi dilakukan di Instalasi Pelayanan Jantung Rumah Sakit Dr. Hasan Sadikin Bandung oleh seorang konsultan kardiologi anak dengan menggunakan mesin ekokardiografi dari General Electric vivid 7 dengan probe $\mathrm{m} 4 \mathrm{~S}$.-

Status gizi ditentukan oleh indeks masa tubuh terhadap usia (IMT/U) pada WHO 2007. Apabila $Z$-score IMT/U <-2 SD maka masuk gizi kurang dan $Z$-score IMT/U < -3 SD maka masuk gizi buruk. Gizi normal adalah $z$-score IMT/U $>-2$ s/d $<1$ SD.

Dengan posisi anak terlentang tenang, simultan dengan EKG mencakup pandangan parasternal, apical, subcostal dan suprasternal costal untuk menilai bahwa tidak ada kelainan anatomi jantung. Pemeriksaan myocardial performance index (MPI) dilakukan dengan menempatkan kursor yang ditempatkan pada ujung katup mitral pada pandangan 4-chamber untuk menghitung a yang merupakan interval waktu antara akhir dan awal dari aliran transmitral. Kursor kemudian diletakkan di left ventricle outflow tract (LVOT) di bawah katup aorta pada pandangan 5-chamber untuk menilai b. Nilai a didapatkan dengan menggabungkan isovolumic contraction time (IVCT), isovolumic relaxation time (IVRT), dan ejection time (ET). Sehingga rumus MPI menjadi a-b/b atau seperti tertera di bawah ini yaitu,

Myocardial performance index untuk menilai fungsi sistolik dan diastolik sekaligus yaitu dengan rumus:

$$
\mathrm{MPI}=\frac{\mathrm{IVCT}+\mathrm{IVRT}}{\mathrm{ET}} \text { atau } \frac{([\mathrm{KMt}-\mathrm{KMb}]-\mathrm{WE})}{\mathrm{WE}}
$$

$\mathrm{MPI}=$ Myocardial performance index, $\mathrm{IVCT}=$ Isovolumic contraction time, $\mathrm{IVRT}=$ Isovolumic relaxation time, $\mathrm{ET}=$ Ejection time, $\mathrm{WE}=$ Waktu ejeksi, $\mathrm{KMt}=$ Katup mitral menutup, $\mathrm{KMb}=$ Katup mitral membuka

Nilai normal MPI kiri adalah 0,35 (SB 0,03). Pada anak kurang dari 3 tahun 0,40 (SB 0,09); anak umur lebih dari 3 tahun 0,33 (SB 0,02). Pada kardiomiopati dilatasi 0,78 (SB 0,28). ${ }^{5,6}$

Pengujian untuk menilai kemaknaan dari data numerik untuk 2 group digunakan uji $\mathrm{T}$ berpasangan 
(T-paired) pada data distribusi normal. Kemaknaan hasilnya ditentukan berdasarkan $\mathrm{p}<0,05$. Piranti lunak SPSS Statistic ver. 17.0 (Windows) digunakan dalam keseluruhan analisis data.

\section{Hasil}

Penelitian ini melibatkan 60 anak yang terdiri dari 28 anak perempuan dan 32 anak laki-laki dari 10 Sekolah Dasar di Kotamadya Bandung. Kelompok gizi kurang dan gizi normal masing-masing 30 anak. Keseluruhan anak pada kelompok gizi kurang (kelompok I) memiliki z-score IMT/U: <2SD, tidak didapatkan gizi buruk pada pengambilan sampel.

Dari Tabel 2 di atas ditemukan tidak ada perbedaan yang bermakna dari MPI ventrikel kiri diantara kelompok gizi kurang dan kelompok gizi normal.

Tabel 1. Profil klinis kelompok gizi kurang dan gizi normal

\begin{tabular}{|c|c|c|}
\hline Karakteristik sampel & Kelompok $1(\mathrm{n}=30)$ & Kelompok $2(n=30)$ \\
\hline \multicolumn{3}{|l|}{ Usia } \\
\hline Rerata (SB) & $8,8(1,6)$ & $8,8(1,5)$ \\
\hline \multicolumn{3}{|l|}{ Jenis kelamin (\%) } \\
\hline Laki-laki & $15(50)$ & $13(43,3)$ \\
\hline Perempuan & $15(50)$ & $17(56,7)$ \\
\hline \multicolumn{3}{|c|}{ Kehamilan (\%, Minggu) } \\
\hline$<37$ & $2(7)$ & $4(13)$ \\
\hline $37-42$ & $28(93)$ & $26(87)$ \\
\hline \multicolumn{3}{|l|}{ Berat lahir $(\%, g r)$} \\
\hline$<2500$ & $1(3)$ & $3(10)$ \\
\hline$\geq 2500$ & $29(97)$ & $27(90)$ \\
\hline \multicolumn{3}{|l|}{ Berat badan } \\
\hline Median $(\mathrm{kg})$ & 20 & 23,6 \\
\hline Range & $18-23$ & $16-26$ \\
\hline \multicolumn{3}{|l|}{ Tinggi badan } \\
\hline Median $(\mathrm{cm})$ & 124 & 128 \\
\hline Range & $105-134$ & $110-138$ \\
\hline \multicolumn{3}{|l|}{ Tekanan sistolik } \\
\hline $\operatorname{Median}(\mathrm{mmHg})$ & 90 & 90 \\
\hline Range & $85-110$ & $85-110$ \\
\hline \multicolumn{3}{|l|}{ Tekanan diastol } \\
\hline Median $(\mathrm{mmHg})$ & 60 & 60 \\
\hline Range & $55-80$ & $55-80$ \\
\hline \multicolumn{3}{|l|}{ Denyut jantung } \\
\hline Rerata (SB) & $97(13,95)$ & $94(11,65)$ \\
\hline
\end{tabular}

Tabel 2. Perbedaan fungsi ventrikel kiri pada anak gizi kurang dan gizi normal

\begin{tabular}{llcccc}
\hline No & MPI & Kelompok 1 $(\mathrm{n}=30)$ & Kelompok 2 $(\mathrm{n}=30)$ & CI95\% & $\mathrm{p}$ \\
\hline 1 & Ventrikel Kiri & & & & \\
\hline & rerata (SB) & $0,37(0,07)$ & $0,35(0,08)$ & $-0,012-0,058$ & $0,191^{*}$ \\
\hline
\end{tabular}

${ }^{*}$ Uji T berpasangan

Catatan : Kelompok 1 : Anak dengan gizi kurang, Kelompok 2 : Anak gizi normal 


\section{Pembahasan}

Perubahan struktur jantung pada anak gizi kurang akan berkontribusi terhadap massa otot dan fungsi jantung. Pada anak gizi kurang didapatkan kegagalan penghantaran metabolisme yang dibutuhkan miokardium, berkurangnya sintesis komponen miofibrilar, peningkatan katabolisme protein miofibrilar, dan peningkatan sintesis kolagen. Peningkatan sintesis kolagen akan menyebabkan kekakuan dari miokardium yang akan menyebabkan disfungsi diastolik miokardium. ${ }^{7}$

Pemeriksaan fungsi ventrikel pada anak gizi kurang telah dilakukan pada beberapa penelitian sebelumnya. Penelitian yang dilakukan oleh Ocal $\mathrm{dkk}^{9}$ pada tahun 2001 dan Olivares ${ }^{8}$ pada tahun 2005 melaporkan tidak ada perbedaan fungsi sistolik ventrikel kiri dengan parameter perhitungan fungsi sistolik ventrikel kiri, yaitu ejeksi fraksi dan fractional shortening pada pasien gizi kurang dibandingkan dengan gizi normal. Namun, terdapat perbedaan dari masa otot ventrikel kiri dan gambaran elektrokardiografi di antara kelompok gizi kurang dan gizi normal.

Pada suatu penelitian yang dilakukan oleh Jain $\mathrm{dkk}^{10}$ pada populasi anak gizi buruk yang mendapat perawatan di rumah sakit disebutkan bahwa untuk mendeteksi awal gangguan fungsi jantung dapat dilakukan dengan pemeriksaan MPI untuk melihat fungsi miokardium sebelum lebih lanjut lagi diperiksa dengan metode konvensional dengan memeriksa ejeki fraksi.

Ekokardiografi transtorakal dilakukan pada anak sehat berusia 6-11 tahun dengan status gizi gizi kurang dan gizi normal yang dilakukan matching pada usia dan jenis kelamin. Hasil Pemeriksaan MPI pada anak dengan gizi kurang menunjukkan hasil yang lebih tinggi dari pada anak gizi normal, tetapi secara statistik tidak ada perbedaan yang bermakna pada fungsi ventrikel di antara 2 kelompok. Berdasarkan penelitian ini, fungsi ventrikel kiri pada anak gizi kurang tidak ditemukan perbedaan dengan anak gizi normal. Hal ini berbeda dengan penelitian yang dilakukan oleh Faddan $\mathrm{dkk}^{7}$ Jain dkk, ${ }^{10}$ dan Meena $\mathrm{dkk}^{11}$ yang menunjukkan adanya disfungsi ventrikel pada anak dengan gizi buruk, tetapi sejalan dengan Ocal dkk dan Olivares $\mathrm{dkk}^{8}$ yang menyebutkan tidak terdapat perbedaan bermakna pada fungsi jantung yang dihitung dengan metode konvensional. Perbedaan ini mungkin disebabkan oleh penelitian yang dilakukan Faddan dkk, Jain dkk, ${ }^{10}$ dan
Meena dkk ${ }^{11}$ menggunakan jumlah sampel yang lebih banyak pada anak dengan gizi buruk.'

Myocardial performance index akan meningkat pada anak dengan penurunan fungsi jantung. Penilaian MPI merupakan salah satu pemeriksaan non invasif untuk menilai fungsi sistolik dan diastolik dari jantung. Perhitungan indeks tidak berdasar dari geometri atau penilaian volume, tetapi penilaiannya berdasarkan rasio interval waktu. Pemeriksaan MPI tidak dipengaruhi juga oleh tekanan darah, denyut jantung, dan usia. Penilaian fungsi jantung dengan metode klasik, yaitu ejeksi fraksi untuk menilai ventrikel kiri dipengaruhi oleh geometri jantung sehingga hasilnya kurang akurat apabila dibandingkan dengan menilai fungsi ventrikel kiri dengan metode MPI. ${ }^{5}$

Berdasarkan teori yang di kemukakan oleh Fioretto $\mathrm{dkk},{ }^{4}$ seharusnya terdapat gangguan fungsi ventrikel kiri pada anak gizi kurang, tetapi pada penelitian ini didapatkan hasil tidak adanya perbedaan yang bermakna pada fungsi ventrikel kiri pada anak gizi kurang dibandingkan dengan gizi normal. Hal tersebut kemungkinan karena durasi kronisitas gizi kurang tidak diketahui serta derajat gizi kurang pada subyek penelitian ini bukan gizi buruk dan metode penelitian potong lintang yang merupakan keterbatasan pada penelitian ini.

Penelitian ini merupakan penelitian pertama dengan subjek anak sehat dengan gizi kurang dibandingkan dengan anak sehat dengan gizi normal dengan metode MPI untuk menilai fungsi jantung. Penelitian ini menunjukkan bahwa gangguan fungsi ventrikel kiri tidak didapakan pada anak sehat dengan gizi kurang.

\section{Kesimpulan}

Sebagai kesimpulan fungsi ventrikel kiri tidak berbeda pada anak dengan gizi kurang dengan gizi normal dengan pemeriksaan MPI .

\section{Daftar pustaka}

1. Penny ME. Protein-energy malnutrition : pathophysiology, clinical consequences and treatment. Dalam: Dugan C, Watkins JB, Walker A, penyunting. Nutrition in Pediatrics. Edisi ke-4.BC Decker Inc.Ontario. 2008.h.174-94.

2. Laporan Riset Kesehatan Dasar (RISKESDAS). Prevalensi gizi kurang di Indonesia. Jakarta: Riskesdas; 2013. 
3. UNICEF-WHO-The World Bank Joint Child Malnutrition Estimate. Levels and Trends in Child Malnutrition. Diakses pada 8 Juli 2021. Didapat dari: https://www.who.int/ nutgrowthdb/2018-jme-brochure.pdf.

4. Fioretto JR, Querioz SS, Padovani CR, Matsubara LS, Okoshi K. Matsubara BB. Ventricular remodeling and diastolic myocardial dysfunction in rats submitted to proteincaloreie malnutrition. Am J Physiol Heart Circ Physiol 2002;282:1327-33.

5. Lokumentas JA, Panou FK, Kotseroglou VK, Aggeli KI, Harbis PK. The of myocardial performance:application in cardiology. Hellenic J Cardiol 2005;46:52-8.

6. Borzoee M, Kheirandish Z. Doppler-Derived myocardial performance index in healthy children in shiraz. Iran J Med Sci 2004;29:85-9.

7. Faddan NHA, El Sayuh KE, Shams H, Badrawy H. Myocardial dysfunction in malnourished children. Annals of Ped Car 2010;3:113-8.

8. Olivares JL, Vasquez M, Rodriguez G, Sampre P, Fleta J. Electrocardiogrpahic and echocardiographic findings in malnourished children. J Am Coll Nutr 2005;24:38-43.

9. Ocal B, Unal S, Zorlu P, Tezic HT, Oguz D. Echocardiographic evaluation of cardiac functions and left ventricular mass in children with malnutrition. J Paediatr Child Health 2013;37:14-7.

10. Jain D, Rao SK, Kumar D, Kumar A, Sihag BK. Cardiac changes in children hospitalized with severe acute malnutrition: A prospective study at tertiary care of northern India. Indian Heart J 2019;71:492-5.

11. Meena R, Suman RL, Meena P, Meena SL. Myocardial performance index in severe acute malnutrition children aged 6 month to 5 years. Int J Contemp Pediatr 2016;3:833-6. 